\title{
Risk Analysis in Professional Terms and Insurance Tariff Algorithm
}

\author{
Asie Tsintsadze ${ }^{1}$, Tamar Gogoberidze
}

\begin{abstract}
Modern society has to live and have activities with risks daily. Consequently, the probability of adverse events is high. In the article, the objective of the research is the risks of professional liability, which, in contrast to other risks, damage the third person. In this kind of insurance, it is difficult to define the amount of damage, the amount of compensation. Therefore, Based on historical facts, an algorithm is designed to determine the professional liability insurance tariff, taking into account the principles of tariff policy and working out the professional rating scale.
\end{abstract}

Keywords: professional Risk, Level of professionalism, Risk of insurance, Net rate, Insurance tariff, risk added

\section{Introduction}

The modern world is the world of risk. The civilization of society, scientifictechnical progress, efficient use of limited natural resources and the growth of human as an important capital is the basis for the emergence of new and existing risks. This process is constantly going on and it's difficult to put in its frame. So, the task of science is to analyze the nature of various risks, accurate classification, and protective mechanisms. Risks exist in nature, but in the case of research, it turns out to be associated with human action, as the effects of damages or loss are only perceived and evaluated by humans.

The paper aims in the basis of the analysis of the historical aspects of professional liability risks, conducted scientific research, studied existing condition in order to expand the professional liability insurance to develop a simple algorithm of the tariff, which will increase the demand for this kind of insurance and contribute to the keeping the human capital in production-organization.

\section{Literature Review}

The science of risk formation and management is connected with the distant past. As history confirms, the scope of risk is expanded with the development of society. In ancient Greek studies, many works in philosophical sciences explain the concept of uncertainty. However, these studies are primarily built on the problem of future uncertainty for every single individual. Mathematicians Blaise Pascal, Pierre de Ferma laid down the quantitative analysis of the uncertainty in the 17th century, after that risk assessment was possible. According to philosophical science "Uncertainty - this is the 
decision-making brain condition or the level of its knowledge on the specific situation". [Diev B.C.] In this definition, the decision of human subconscious is exacerbated as a risk factor.

Risk management theory considers operational risks among the inconvenience risks of planning results of production-organization. Operational risk generation is discussed in two directions: 1. Risks originating with objects (building-construction, machinery and 2. Risks related to human capital. In the first case, assessment can be evaluated using mathematical methods and is managed by risk management methods. In the second case, we are dealing with the subjects whose quality of performance is based on several factors: level of education, level of professionalism, personal qualities, psychoemotional characteristics. [Suslyakova O, ..... 2018].

In the history of economic thought, William Pete, the classical political economist spokesman in his work "political arithmetic" human capital described as follows: "The live acting power of human" and noted that this is part of national wealth. [William P,...1681] Pete explains that human capital as the driving power of the other factors. Human Capital Researchers: John Meiner Clark, I. F. Tunen, A. Marshall, S. Fischer and others Despite the different interpretations of the definition, focus on the workforce qualifications. The attention of the economic thinkers is less likely to be influenced by human capital research on the impact of risks on the results of their production, their psychological portrayal, even in the case of high qualifications, the possibility of operating risks.

Transition to market principles strengthened competition in both physical and human capital. Technical progress has been made in the field of physical capital - as a guarantee of successful performance of organizations as well as the generating of new risks. Human capital has been subjected to competition and numerous risks.

In the countries of the post-Soviet space where 70 years [1921-1990] were characterized by total employment, the compensation inflicted by professional risks was done by the state. In modern times, attitude towards professionalism is less considered in terms of risk. The reduction of participation in the regulation of stated loos caused the break of stereotypes of traditional forms of professionalism. The risks of professional liability in the performance of the assigned functions are considered as operational risk according to risk management theory, its analysis and evaluations are carried out by expert methods, which are highly probable subjective and increase the indefinite obtainable outcome. The insurance companies could ensure professional liability risks according to the compliance of accident and possibility, but the expected damage by the professional liability risk of one individual cannot be measured.

Despite historical researches, methods and models created by modern science, risk assessment, accurate analysis and precisely predictable results would not be possible to predict accurately. The risk classification has created the possibility of proper and correct management methods according to the source and the expected outcome. The emergence of new risk factors reduces the efficiency of existing management methods, in some cases it is useless. In the modern period, the growth of globalization, application of artificial changes in natural-climatic conditions, expansion of economic ties to increase profits, thus improving or increasing existing or raising risks. These factors do not claim the formation of a comprehensive classification of risks, but the principle that protection 
of a compensation risk from a specific risk is based on the accuracy. The first form of human dependence on the risk is derived from the primordial community of origin, the basis of which is a risk of food production in the future. Later, when human activity acquired an economic character, the content of the threat was expanded. In particular, the possibility of a favourable accident was added to the disadvantages. It is essential to separate the risk and danger from each other. The risk and danger are discussed in one context when the net risks are analyzed and speculative risks are not used to assess anticipated risks. Depending on this view, threats to insurance are subject to insurance protection, and speculative risk factors are risk management principles.

Risks according to theory and practice are classified as clear and speculative risks. Which group belongs to professional risk? The net risk is negative and the speculative positive results are considered. On one hand, professional risks are attributable to the net risks group, but the professional risk may also be successful in the sense that the decision made by a professional person may be profitable. For example Stock Market Dealer, Arbitration, Financial Manager, State Manager, Politician, etc. First of all, the definition of the professional-rights-liabilities framework is necessary for a full explanation of professional risk. History knows the facts when nobles: kings, monarchs are steeped in all boundaries and act against the law, causing moral, physical and material damage to the entire community or its members. For example, In 1215, King John of England was forced to sign the Freedom Charter, in order to avoid further action of the manager, and the examples of the string of Elizabeth I have been exposed to the personnel of the palace. The historical form is based on the change in the work.

\section{Research Methodology}

One of the researchers considers professional risks, as in the case of industrial trauma and disease, an entrepreneur's expenditure and the insurance of an employee. [Khrupacheva A,... Khadartseva A,.. 2011]. In this article, the professional risk is considered as the risk of improper performance or failure to account for a third person. In this case, the person who performs professional activities and not the entrepreneur. Consequently, we consider it as an individual risk. In order to clarify more professional risks, we should divide them into two categories:

1. Risks arising from technical and technologically threatening factor;

2. Risks arising out of a person's actions or inactivity while performing professional duties;

V. Roiki in the work " Professional Risks: Analysis and Management Problem" discusses professional risks associated with social insurance "One of the types of professional risks, as technological risks, is relevant. First of all, it is related to the development of compulsory social insurance mechanisms to provide insurance protection for the risks of industrial accidents and professional diseases". In the same work, Roy describes the problem of studying professional risks caused by a complex nature, diversity, difficult predictable future, etc. [Roik V... 2003]. In the opinion of the author, V. Roiki's approach is acceptable for professional risk management, but it does not include analysis and assessment of the risks expected in professions. Discussion of professional risks is incomplete only due to the risk of industrial accidents and 
professional diseases. As mentioned above, it should be added to the danger of the possibility of making a mistake when performing the duties of a particular profession. Only complex assessments can be made to professional risk analysis, evaluation and preventive management measures.

Risks of individual professions are characterized by different factors and changes in time with the change of factors. Hence, the risks associated with the fulfilment of different professions should be considered as a separate object of research. The activity of individual professionals has a chance of accidental and probability, whereby the insurance risks take the status, but when it comes to insurers, they are important. In case of the first category of professional insured risks, the insurer should be an entrepreneur and the insured payer, as he/she is insured for the accident of the employee (third party) when performing specific activities. This type of insurance is the risk of liability insurance - professional liability insurance. As for the second category of professional risks, the insurer is a professional and the third person insured, unknown when signing a contract. The insurance premium will be paid by a person carrying a professional risk. As we can see, in case of both professional risks, they are different. Therefore, insurance tariff should be different.

Professional liability insurance is on the edge of two subdivisions of the insurance: property and personal, according to the insurance tariff should be determined by the third person subject or object. In the case when it is considered to be responsible for damages, the insurance tariff should be performed by risky insurance tariff accounts. When professional liability insurance is a third party, this is the subject - this type of insurance is transferred to the subprime of personal insurance. Personal insurance directly examines the damage inflicted on the person. One of the most vulnerable occupations is the risk of professional liability insurance for the risk of harming human health and life. This type of insurance is an invaluable insurer. Therefore, the insurance tariff algorithm should be based on the cost of the solvency of the professional. One of the principles of tariff policy should be "fit to pay the insurer" and at the same time to ensure the financial sustainability of the insurance company. At the same time, net rate algorithm is simple and the insurance payer must be understandable [Veeh J...2006].

According to the current method of producing actuarial accounts, the main part of the insurance tariff is the net rate, which in turn has two elements: the main net rate and risk-additive.

\section{$T_{\text {neto rate }}=T_{\text {bazis }}+T_{\text {Risk added }}$}

Where $\boldsymbol{T}_{\text {neto }} \boldsymbol{r a t e}^{--}$is the net interest rate;

$\boldsymbol{T}_{\text {bazis }^{--}}$the main part of the net rate;

$T_{\text {Risk added }}$ - Risk plug-in.

Internal and external factors affect the emergence of professional risk. One of the most important factors is the level of professionalism of the insurer. The level of professionalism, the higher the probability of the insurance case and therefore the risks of the insurer's bankruptcy. Psychologist A. Druzhilov uses a three-level system to evaluate the level of professionalism: low level - study or potential; Medium - the standard level of professionalism; High - optimal professionalism and "master" - the highest professionalism.[C. A. Drujilov... .2012] According to Drujilov method, the gradation of professionalism is subdivided and measured by 1-9 points. Namely: 
Table№1.[C.A. Drujilov....2012]

\begin{tabular}{|l|c|l|c|}
\hline Level and subfield of professionalism & 4 \\
\hline High & 9 & Nominal & 3 \\
\hline Optimal & 8 & Beginning & 2 \\
\hline Perspective & 7 & Educational & 1 \\
\hline Average & 6 & Potential & \\
\hline Major & 5 & & \\
\hline
\end{tabular}

Proposed charting can be used in the formula for calculation of professional liability insurance tariffs. Access to the following should be taken into consideration: The level of professionalism is calculated by the risk coefficient of which the rank is low, medium and high grade.

There are many methods of calculating the risk coefficient. In this case, we used the ratio $\mathrm{K}=1 / \mathrm{L}$ where $\mathrm{L}$ is the average level of points awarded according to the gradation of professionalism:

High level of professionalism $-\boldsymbol{L}_{\boldsymbol{h i g}}=\frac{7+8+9}{3}=8$

The average level of professionalism- $\boldsymbol{L}_{\text {ave }}=\frac{\mathbf{4 + 5 + 6}}{\mathbf{3}}=\mathbf{5}$

Low level of professionalism $-\boldsymbol{L}_{\text {low }}=\frac{\mathbf{1 + 2 + 3}}{\mathbf{3}}=\mathbf{2}$

The risk ratios will therefore be:

$$
\begin{aligned}
& \text { 1. } K_{\text {hig }}=\frac{1}{L_{\text {hig }}}=\frac{1}{8}=0,125 \\
& \text { 2. } K_{\text {ave }}=\frac{1}{L_{\text {hig }}}=\frac{1}{5}=0,2 \\
& \text { 3. } K_{\text {low }}=\frac{1}{L_{\text {low }}}=\frac{1}{2}=0,5
\end{aligned}
$$

Table №2: Level of professionalism

\begin{tabular}{|l|c|c|c|}
\hline \multirow{2}{*}{$\begin{array}{l}\text { Risk } \\
\text { Coefficient }\end{array}$} & \multicolumn{3}{|c|}{ Level of professionalism } \\
\cline { 2 - 4 } & $\operatorname{High}(7,8,9)$ & Medium(4,5,6) & Low $(1,2,3)$ \\
\hline High $(0.5)$ & & & $\mathrm{X}$ \\
\hline Medium $(0.25)$ & & $\mathrm{X}$ & \\
\hline Low $(0.125)$ & $\mathrm{X}$ & & \\
\hline
\end{tabular}

Source: Author's calculations

Reflecting the coefficients received in the main part of the net rate increases or decreases the net rate according to the level of professionalism. The tariff algorithm can be based on the principle of tariff acceptance to quantitative evaluation of the impacts of determinant components for acceptance of tariffs as for the insurer and the insurer.

One of the biggest problems in building a professional risk insurance tariff is to collect statistical information. The diversity of professions, different outcomes of insurance incidents, various factors causing elaboration of a single insurance tariff algorithm for this sector of insurance. Assessment of professionalism above can be 
different for individual professions, so the principle that should be based on the tariff construction is the following: "High professionalism-low risk."

\section{Results}

The algorithm developed by the author is based on the following components:

A. risk coefficient - K;

B. The frequency of mistakes made in the performance of professional activities (calculated at the frequency of the number of insurance incidents in the field of specific professional activities (calculating at least 15 years) --- $\mathrm{p}$;

C. Remuneration of the insured (annual) - S;

D. Insurance amount (maximally compensated limit) - Z.

The main part of the net insurance rate is $\mathbf{T}_{-}$basis $=\mathbf{K} \times \frac{\boldsymbol{S}}{\boldsymbol{Z}} \times \mathbf{p}$

In this formula, the ration of the labour remuneration and compensation loss (insurance amount) reduces or increases the insurance tariff. In particular, inadequate selection of the insured amount by the insurer in the case of high salaries, however, reduces the insurance tariff and thus the revenue of the insurance portfolio, but increases the limit of personal liability of the insurer.

Assignment: Components included in the formula: Risk coefficient, remuneration and compensation limit should be taken in accordance with the expected maximum loss (except death) of the profession and insurance case;

Depending on the probability of insurance activity, it is necessary to add a net rate to provide sustainability, which will be used to cover cases of excessive losses. The methodology for calculating the risk-additive needs to calculate the average square deviation that is related to obtaining great information. The presented algorithm is based on the insurer's data and reflects the possibility of paying the insurance premium. Risk plug-in is not included in the policyholder's interest, but the company's reliability to the net rate of participation in the main part of the insurance portfolio will be multiplied by the probability of the occurrence of the insurance is intended to guarantee the safety coefficient, which is taken by the insured at the time of the company's Financial Status According to Adobe.

\section{Thus, $\boldsymbol{T}_{\mathbf{R} \mathbf{p}}=\boldsymbol{T}_{\text {bazis }} \times \mathbf{p} \times \mathbf{y}$}

Where the probability of the accident insurance case is in the professional risks insurance portfolio;

y - Security Guarantee Coefficient of Insurance Company, which will be chosen by Financial Management to evaluate the financial sustainability of the portfolio and take out from a special spreadsheet.

The formula for the risk of professional liability risks will be finalized as follows:

$T_{\text {netto }}=T_{\text {bazis }}+T_{\text {bazis }} \times \mathbf{p} \times \mathbf{y}=\boldsymbol{T}_{\text {bazis }}(1+\mathbf{p} \times \mathbf{y})$

The insurance tariff (curve rate) is calculated by the general formula used in the actuarial accounts:

$$
T_{b r}=\frac{T n}{1-f}
$$

Where - $f$ - is the cost of the case of the insurance company. 
The adopted algorithm is simple and the insurer is aware of the insurer, namely the insurer in the $\boldsymbol{T}_{\text {bazis }}$, which ensures that the level of professionalism, the high insurance tariff should be pa id. It is also important that the probability of the mistakes made is correct, indicating a potential insurer on the necessity of insurance. Involvement of the salary pay rate The calculation of the tariff serves to preserve the principle of access to the insurance tariff. Finally, the insurance premium is calculated by multiplying the insurance tariff (insurance rate) by the amount of insurance sum:

\section{insurance premium $=\mathrm{T}_{\mathrm{br}} \times \mathrm{Z}$}

For the calculation of fair insurance tariffs, the professional liability insurance portfolio should be divided into the lower, medium and high levels according to the professionalism and risk coefficient. Such division allows for the probability of the insurance accident and the reliability guarantee coefficients in each of them. The insurance tariff calculation formula is adjusted according to each parameter. This ensures the maintenance of the insured as well as the insurer's financial position during the insurance case.

Advantages of the presented methodology are:

A. Use of professional risk factors for individual insurers;

B. The simplicity of calculation;

C. Simplification of obtaining the necessary indicators for calculation;

D. Raise the level of confidence to the insurer.

This method can be used to calculate different risk insurance rates. The methodology has been developed for low-cost insurance countries where the risk of professional liability is a small share of the insurance market Degree reasons:

A. Low insurance culture;

B. Low responsibility while performing professional activities;

C. low-quality confidence in insurance companies;

D. Low corporate culture.

The practice of developed countries shows that there is no profession which does not have liability insurance. Moreover, it deals with professions related to people's lives.

In some countries, there is a special law, whereas the profession is related to hazardous activities to have professional liability insurance.

\section{Discussion}

Professional liability insurance in developing countries is a demanding product but it is not possible to analyze its share and make parallel with developing countries because the results of professional liability insurance are reflected in the general liability insurance coverage of the international organization [OECD.STAT Insurance Indices, .... 2017)]. Table №3 shows that the share of the total premium attracted by all products of liability insurance excluding non-life insurance is the highest in the UK $(27.6 \%)$ and in the rest of the country varies within $3-9 \%$.

The quality of professional risks in Georgia is high, as there is no credible criterion for professionalism and the recruitment is done by testing and interviewing methods, in case of confirmation by the relevant qualification document. Methods have a 
high margin of error between real and demanded professionalism. Such a situation is a challenge to offer professional insurance products from insurance products. Since 2005, as a civil liability insurance policy, and from 2007 on specific professions. Of the 16 insurance companies operating in the country, five companies offer professional risk insurance, but its share is only $4 \%$ of the insurance market. The reasons for development are the use of professional liability insurance in a non-formal manner, weak punitive measures for the misuse of the case. For example, it is used for improper medical practice: a) written warning; B) to cancel/cancel the state certificate. In this approach, the responsibility of a professional is ignored in the material security of the victim. According to the information provided by researchers from individual researchers, doctors' mistakes are one of the causes of death (US, Great Britain, New Zealand, the Netherlands, Russia ...). In Georgia, where a low level of professionalism is low, professional responsibility is very difficult. According to statistical information in the small population (3,5 million) in 2016-2018, 62 doctors and newborns were killed due to physicians' mistakes.

\section{Conclusion}

Professional risks the following form on the peculiarities will always be in the centre of risk research science. The main problem that prevents the development of this type of insurance is:
A. low culture of general and especially professional responsibility of citizens;
B. carry out improper measures in case of stated risk;
C. low insurance culture;
D. unreliable mechanism of professionalism assessment;
E. absence of classification of the risk characteristic of individual professions;
F. low-level social responsibility for producing-organizational heads.

The insurance tariff algorithm developed in the paper can not alleviate the problems listed, but the potential insurer will be able to understand the risk of liability in accordance with his professionalism. This will increase trust in insurance companies. Based on the quantitative assessment, the fair tariff will be a double result. First, the professions will be maintained and developed and the second, the revenue of insurance companies will be expanded, which will facilitate the supply of financial markets with temporary free cash resources.

\section{Recommendations}

1. Introduction of compulsory insurance for professional liability risks for endangered companies;

2. Developing the scale of the professional level;

3. To attract people with different professions, insurance companies use a lower limit of $15 \%$ for optimizing insurance tariff.

4. Responsibility for maintenance of professional staff from the heads of organizations. 


\section{References}

Bajtelsmit V., Thistle P. D., (2008) "The Reasonable Person Negligence Standard and Liability Insurance", The Journal of Risk and Insurance, Vol. 75, No. 4, pp. 815-823 https://doi.org/10.1111/j.15396975.2008.00286.x

Boyer M. M., Tennyson Sh., (2015), 'Directors' and Officers' Liability Insurance, Corporate Risk and Risk Taking: New Panel Data Evidence on The Role of Directors' and Officers' Liability Insurance/ The Journal of Risk and Insurance “, Volume82, Issue4, Pages 753-791. https://doi.org/10.1111/jori.12107

Denisov D. V., Kotlobovski I. B., (2013) “Actuarial calculations in insurance. Tutorial”, Moscow (Аенисов А. В., КотАобовский И.Б.,(2013) “Актуарные расчеты в страховании. Учебное пособие”, Москва

Diev V. (2011) "Risk and uncertainty in philosophy, science, management", Reporter of the Tomsk State University, №2 (14), p.79-89 (Аиев В.( 2011), “Риск и Неопределенность в Философии, Науке, Управлении”, Вестник Томского Госсударственного Университета , №2(14), р.79-89)

Druzhilov S. (2012) "Crteria and levels of individual profesionalizm", Siberian state industrial university, Novokuznetsk--Scientific journal Modern problems of science and education, № 1

Hwang Jh., Kim B.,(2018) "Directors and officers liability insurance and firm value", The Journal of Risk and Insurance Volume 85, Issue 2Pages: 301-595. https://doi.org/10.1111/iori.12136

Iglz R. (2008) "The history of England", Home historical history reference-translation from English, Gogevtsov, Publisher: ACT, Astral, 294 р. (ㄷлз Р. (2008), "История Англии. Подворный исторический справочник по истории-пер. с англ. Гогевцова, Издательство: АСТ, Астрель, 294 c)

Kahane K, ,The theoty of inasurance risk premiums-A Re- Examinaton in the light of recent developments in capital market theory", The ASTIN Bulletin 1o ( 979 ), 223-239, https://www.actuaries.org/Librery/Astin/vol. 10 no2/223.pdf

Kapral s. (2013), "Differentiation of views on the risk definition and uncertainty", Reporter of Tomsk State University, Number: 2 (22) Pages: 33-39 (Капралин С.(2013), “Аиференцияция взглядов на Аефиниции „Риск“ и „Неопределенность“ Вестник Томского Государственного Университета, №2 (22), Страницы: 33-39).

Makary M. M., Daniel M., (2016) "Medical error is not included on death certificates or in rankings of the cause of death" Department of Surgery, Johns Hopkins University School of Medicine, Baltimore, MD 21287, USA, 03.05. https://doi.org/10.1136/bmj.i2139

Mastin L. (2010)" The Story of Mathematics", Available at http://www.storyofmathematics.com/17th pascal.html

Mihaela D. (2015), A Review of Theoretical Concepts and Empirical Literature of Non-life Insurance Pricing, Procedia Economics and Finance, Volume 20, 2015, Pages 157-162

Pitkanen P. "Tariff theory", available at https://www.casact.org/library/astin/vol8no2/204.pdf

Roik V. (2003), “ The Professional Risk: The problems of analysis and management”, Journal "human and Labor", $\quad$ https://www.ippnou.ru/article.php?idarticle $=000165 \quad$ (РОИК $\quad$ B.(2003), "Профессиональный риск: проблемы анализа и управления", Журнал "Человек и труА" https://www.ippnou.ru/article.php?idarticle $=000165$ )

Ryagin Yu. I., (2018) "Riskology in 2 Ch. Part 1", Textbook for universities, Ekaterinburg (Рягин Ю.И., (2018) “Рискология в 2Ч, Часть №1", Учебник Аля вузов, Екатеринбург)

Simonova N. (2015), "Assessment of an Individual Professional Risk", Labor Protection and Fire Safety, No. 4 (Симонова Н,(2015), „Оценка индивидуального профессионального риска”, Охрана труда и пожарная безопасность», № 4)

Susliakova O., (2018) „Innovative economy, prospects for development and improvement”, Insurance of Professional Responsibility of Medical Workers, No.8, p.34 (Суслякова О., (2018) „инновационная экономика, перспективы развития и совершенствования”, Страхование Профессиональной Ответственности Медицинскых работников, №8, p.34).

Veeh J. A., (2006) "Lecture Notes on Actuarial Mathematics" 
Vopopaev A., Voropaeva I., Isaev Yu., (2006)," Insurance of Professional Responsibility of Medical Workers”, Siberian Medical Journal (Irkutsk) №2, p.104-106 (Воропаева И, Исаев Ю. (2006), “Страхование Профессиональной Ответственности Медицинскых работников,", Сибирский медицинский журнал (Иркутск) №2, p.104-106)

Organisation for economic co-operation and development, Insurance indicators, 2017. 